\title{
Materials of State and Local History in College Libraries
}

T NATURALLY is the function of every 1 college librarian to collect and preserve the source materials comprising the history of his college. Also, inasmuch as the history of the college is more or less a part of that of the community, the librarian has an obvious duty as regards local history materials. When in the community there exists also a public library or an official or quasi-official historical society with adequate equipment, personnel, and funds to maintain the local history library and archives, the college librarian's direct responsibility may end with his institutional collection. Under such conditions, however, he does have an obligation to put whatever agencies may be charged with the local collections in touch with such source materials as may come to his attention through gifts or purchases offered to the college. This implies the conclusion of such contracts with donors as may be necessary to permit transfer of title and, in the case of items offered for sale, the transmission of the sale information to the proper institution.

With respect to the records of state history, a similar responsibility exists to the state historical society or other agency commissioned by the state. Beyond that I question whether the majority of colleges can justify entering the field of state history except, of course, for the basic reference and more or less secondary source materials.

Upon the vast majority of college li-

1 Based on a statement presented before a joint session of the Society of American Archivists and the American Association for State and Local History at Princeton, N.J., Nov. I6, I943. brarians, however, in small to medium-sized towns and cities, in their relationship to the strictly local history collection, there rests a more direct, though perhaps somewhat less distinct, responsibility. I use the term "responsibility" advisedly. No thinking person will deny that the sources of local history must be preserved. If in a community there is no other institution charged with that duty, or none able to fulfil it, the task should be assumed by the local college, whether publicly or privately supported. The obligation of the tax-supported college library is fairly clear. In the case of the private- or denominationalsupported colleges, however, the freedom from legal accountability to their communities has too often and too long led the librarians of those colleges to ignore or at least to overlook the rightful obligations of their institutions to the communities.

Under our democratic concept of freedom of education, we exist as tax-free institutions while enjoying essentially the same benefits of government as does the taxpaying business and industrial organization. It is right that we should receive these privileges. Nevertheless, we must not forget that, by this waiver of taxes, a community deprives itself of the tax income on what frequently amounts to many acres of improved property in the very heart of its most highly appraised areas-the very income which might be used to increase the facilities of the public library or historical society. It follows that so long as the college libraries enjoy exemption privileges, 
they must recognize their obligation and seek means of discharging it. One such means may well be constant and effective efforts toward acquiring, preserving, and making accessible the materials of local history, always in planned cooperation with such other agencies as may exist, i.e., the public. library or the historical society.

\section{How to Begin}

Assuming that the college librarian accepts the obligation, how shall he discharge it? If no public library or historical society exists in the community, the college library will create and maintain as nearly complete a collection of printed and manuscript sources of local history as is possible within the limitations of its plant, staff, and budget and of its ability to obtain additional funds for the work. Such funds might reasonably be expected from the local government through an annual appropriation made to the college library in lieu of the support of an historical society or public library, or from private citizens, perhaps through a local chapter of the now-famous Friends of the College Library groups. Without financial aid from the outside, the librarian may be able only to store, without processing, such local history materials as he can acquire. Even this is better than permitting them to go into oblivion.

Where college library, public library, and historical society exist side by side in a community, the conditions, though somewhat more complicated, are potentially ideal for the creation and maintenance of the local history collection, because of the greater diversity of available plant, equipment, and personnel facilities. There are, however, obstacles which must be surmounted. One is the fact that, perhaps unfortunately, most college and public librarians are neither historians nor archivists. However, their training more nearly fits them for the job of preserving and making accessible the printed and manuscript sources of local history than does that of anyone else in the community.

Unfortunately the disinterested librarian is not the only possible obstacle to a program of collaboration. The curators and other active members of local historical societies are often so enthusiastic in their collecting of the written and printed sources and relics of local history as to be unconcerned about the accessibility of their treasures. Moreover, although they may not be prepared by training or equipment properly to handle printed and manuscript materials, their collector's instinct makes it difficult for them to surrender any such materials into what they suspect of being well-trained but unloving hands. I do not wish to minimize the importance of enthusiasm in the collection of local history records. It is extremely important, but so also is the proper preservation and accessibility of that which is collected. If the necessary enthusiasm, training, and equipment are not combined in a single individual or institution, then cooperation is the only answer if the sources of local history are to be preserved, and that for the sake of the future rather than in fond memory of the past.

That collaboration is possible, at least on paper, is evidenced by the various war records commissions set up recently in practically every state, county, and hamlet in the country, which usually involve the local libraries and historical societies. Incidentally, I have often wondered why we seem to be so much more concerned with the preservation of the records of our community in a war than at peace. I suggest that we be equally diligent in the preservation of our peacetime history. Whatever the period, however, the participating institutions in each community will have to work out their own plan of collaboration, based on the respective equipment, personnel, and funds of each. It will take initiative, time, and even education to complete the job. The 
important thing is to arrive at a scheme and to make it work. What follows here is merely by way of suggestion.

\section{Plans for Cooperation}

The basic record of any cooperative plan and, incidentally, in itself the simplest and the least controversial program for any two or more institutions interested in a local history collection, is that of a union catalog of all materials in their libraries and archives. A further measure of coordination might be the assumption by each of the participants of responsibility for the preservation of certain materials, according to sources. For example, one might collect and preserve the items originating in public and semi-public institutions and offices while another might confine itself to those coming from private organizations. A third agency might give its attention to materials deriving from individuals, such as manuscript letters, diaries, published and unpublished writings of local authors. The most obvious advantage to such a plan is that it would simplify search and acquisition by limiting the sources with which each participating institution would have to maintain contact.

Neither of the plans of cooperation suggested makes allowance for the different techniques and equipment required in the handling and preservation of particular types of source materials, such as books, manuscripts, newspapers, maps, and photographs. Since it is in the technical phases of the job that specialization of equipment and personnel are necessary, the most practicable arrangement would be one assigning certain types of materials, regardless of their sources, to each participating institution on the basis of its ability to handle them. Under this arrangement, for example, all manuscript and archival material would be taken care of by one of the libraries and books and pamphlets by the other, leaving the local historical society charged with the responsibility for collecting and preserving the other vestiges of the community's material culture, such as art, household furnishings, the tools and products of industry -in other words, the natural contents of the local history museum.

The immediate objection to the segregation of items according to their physical type rather than by their point of origin or subject, is that those by and about a particular person, institution, or organization would not be housed together. If, however, an adequate author and subject union cata$\log$ were maintained, the basis for that objection would be minimized and the advantages of the greater opportunity for specialized handling should offset any disadvantages of location. It should not be difficult for the student of local history to consult the union catalog for all material locally available on any given subject ; then, if necessary, to have such material brought together in one or the other cooperating institution on an interlibrary loan basis.

\section{A Special Collection}

Admittedly, any college librarian who enters upon a program of cooperation in the collection and preservation of materials for local history will be taking off in the direction of a so-called special collection. Such collections are a problem to the average American college library and for the most part are difficult to defend as items in the budget. This is especially so when there is little instruction beyond the undergraduate level and none of doctorate nature, in which circumstance the only reason at hand for the maintenance of the collection is that it may some day attract a lone scholar to a research-starved campus for a fleeting glance at something like "a special collection of materials on 'the exquisite but almost legendary Schaukelpferd-Napolean-Coquin- 
Defricassé-Usefóvitch Manuscript of Omniology.' "2

Nevertheless, with full cognizance of the problem, it is recommended that the college librarian find and assume his place in the collection and preservation of materials of local history. His responsibility in that direction has been purposely emphasized, to the neglect of the more obvious compensations which should be apparent to any college librarian. These rewards, however, deserve mention. In the first place, there may be a widening of the college library's circle of friends in the community. Secondly, in the local history collection there may be much that will contribute to the teaching program, especially in the social

${ }^{2}$ The Koh-i-noor of Books . . . by Tydor Debrenowsky [pseud.] Torch Press, ioj8. Privately printed. sciences. After all, the sources of local history do not differ greatly, except in volume and magnitude, from those of state and national history. Through the use of local sources it should be possible to vitalize instruction in methods of research and in the evaluation and use of original materials by college students, especially in the fields of history, economics, sociology, and political science.

Incidentally, although no less important, a cooperative program for the collection and preservation of the materials of local history might well promote coordination of all library facilities and service within a community. This, as all college librarians know, is a matter on which they have talked much but accomplished little.

\section{Bibliographical Importance of Copyright Records}

(Continued from page 40)

hiatus in American bibliography. However, to ignore the copyright records in this undertaking is to ignore one of the most valuable sources that could be used in the compilation.

All bibliographers of regional imprints should find the copyright records of particular interest, especially for certain types of works which are not normally recorded in library catalogs. Bibliographers of special subjects or forms of material will also find a search of the copyright entries productive of much information not otherwise available. Even though they may discover entries for titles which were never printed, yet the act of copyrighting the titles indi- cates an intention to publish which is significant.

Further research needs to be done to establish other ways in which the copyright records may be used. For example, studies might be made to prove the value of the records as sources ( $I$ ) for the printing and publishing history of the nation; (2) for indicating the trends in literary and artistic production; (3) for analyzing the subject matter of copyright. The urgent need, however, is to have the copyright records made immediately accessible, through their publication or by their transcription on cards, in a file which will be centrally located for use by bibliographers. 